9 Vuylsteke B, Laga M, Alary M, Gerniers MM, Lebughe JP, Nzila $\mathrm{N}$, et al. Clinical algorithms for the screening of women for gonococcal and chlamydial infection: evaluation of pregnant women and prostitutes in Zaire. Clin Infec Dis 1993;17:82-8.

10 Grosskurth H, Plummer F, Mhalu F, Mabey D. STD research in Africa. Lancet 1993;342:1415-6.

11 Braddick MR, Ndinya-Achola JO, Mirza NB, Plummer AF, Irungu G, Sirei SKA, et al. Towards developing a diagnostic algorithm for Chlamydia trachomatis and Neisseria gonorrhoeae cervicitis in pregnancy. Genitourin Neisseria gonorrho

12 Mayaud P, Grosskurth H, Changalucha J, Todd B, West $\mathrm{R}$, Gabone $\mathrm{R}$, et al. Risk assessment and other screening options for gonorrhoea and chlamydial infections in women attending rural Tanzanian antenatal clinics. Bull WHO 1995;73:621-30.

13 Konate LD, Sinare T, Seroussi M. Burkina Faso: enquête démographique et de santé, 1993. INSD and DHS, ed. Calverton, Maryland (USA): Macro International Inc, 1994:296.

14 Laga M, Nzila N, Goeman J. The interrelationship of sexually transmitted diseases and HIV infection: implications for the control of both epidemics in Africa. AIDS 1991;5(supp1 1):S55-S63

15 Wong PC, Ho BSW, Egglestone SI, Lewis WHP. Duplex PCR systeme for simultaneous detection of Neisseria gonorrhoeae and Chlamydia trachomatis in clinical specimens. $\mathcal{F}$ Clin Pathol 1995;48:101-4.

16 Lee HH, Chernesky MA, Schachter J, Burczak JD, Andrews WW, Muldoon S, et al. Diagnosis of Chlamydia trachomatis genitourinary infection in women by ligase chain reaction assay of urine. Lancet 1995;345: 213-6.

17 Leroy V, De Clercq A, Ladner J, Bogaerts J, Van de Perre P, Dabis F. Should screening of genital infections be part of antenatal care in areas of high HIV prevalence? A prospective cohort study from Kigali, Rwanda, 1992-1993. Genitourin Med 1995;71:207-11.

18 Kramer MS. Determinants of low birth weight: methodological assessment and meta-analysis. Bull WHO 1987; 65:663-737.

19 Meda N, Soula G, Dabis F, Cousens S, Some A, Mertens T, et al. Facteurs de risque de prématurité et de retard de croissance intra-utérin au Burkina Faso. Rev Epidém et Santé Publ 1995;43:215-24.

20 Chin J. Public health surveillance of AIDS and HIV infections. Bull WHO 1990;68:529-36.

21 Rooney C. Antenatal care and maternal health: how effective is it? a review of the evidence. Geneva: WHO/MSM/92.4, 1992:p74.

22 Ledru S, Meda N, Fofana M, Soula G, Bazie AJ, Chiron $\mathrm{JP}$, et al. Etiologic study of genitourinary infections in women of childbearing age in Bobo-Dioulasso, Burkina Faso, 1992. Sex Transm Dis 1996;23:151-6.

23 Shafer MA, Schachter AJ, Moscicki AB, Weiss A, Shalwitz $\mathrm{J}$, Vaughan $\mathrm{E}$, et al. Urinary leukocyte esterase screening test for asymptomatic chlamydial and gonococcal infections in males. $\mathcal{F} A M A$ 1989;262:2562-6.

24 Lewis J, Kraus S, Lossick J. Use of the urine leukocyte esterase test to screen women for gonorrhea and chlamydia infections. In 94th General Meeting of the American Society for Microbiology. Washington DC, 1994: Abstract C-350.

\section{Historical vignette}

\title{
A Cyprian Ode
}

Says Venus to Cupid, "It grieves me to think What ills my dear votaries befall,

Who, whilst my sweet nectar they eagerly drink,

Too oft find it mingled with gall.

What left-handed Demon thus dashes the bowl, As grudging poor mortals the bliss;

Who sheds the contagion that darts through the soul,

And kills with a treacherous kiss?

Bid Mercury straight go and bind the fell fiend

In chains adamantine, I pray

That lovers may hence give their fears to the

wind,

And joyful proclaim holiday.

From hence let them banish dull sorrow and care,

Needless torture no longer endure;

Lo! I send down Apollo to impersonate

C - - - e, *

Who shall teach them a lenient cure."

^Peter Clare was a London surgeon. He quoted lines about himself in a book on venereal disease which he edited, published in 1783. "Cyprian" formerly meant "lewd". 